\title{
Predation on microcrustaceans in evidence: the role of chaoborid larvae and fish in two shallow and small Neotropical reservoirs
}

\author{
Carolina Figueira Câmara, Maria Stela Maioli Castilho-Noll and Marlene Sofia Arcifa
}

(CFC) Departamento de Zoologia e Botânica - IBILCE, Universidade Estadual Paulista - UNESP. Rua Cristóvão Colombo, 2265, Jardim Nazareth, 15054-000, São José do Rio Preto, São Paulo, Brasil. E-mail: carolinaf_camara@yahoo.com.br

(MSMCN) Departamento de Biologia Aplicada à Agropecuária, Faculdade de Ciências Agrárias e Veterinárias - Universidade Estadual Paulista - UNESP. Via de Acesso Paulo Donato Castellane, s/n, 14884-900, Jaboticabal, São Paulo, Brasil. E-mail: mstela@fcav.unesp.br

(MSA) Laboratório de Limnologia, Departamento de Biologia, FFCLRP, Universidade de São Paulo. Av. Bandeirantes, 3900, 14040-901, Ribeirão Preto, São Paulo, Brasil. E-mail: marcifa@usp.br

\section{Abstract}

This study was focused on the predation upon microcrustaceans by an invertebrate predator (chaoborid larvae), and vertebrate predators (fish), in two small reservoirs in southeastern Brazil, with and without macrophytes, in two climatic periods (dry and rainy seasons). Chaoborus larvae were sampled in the limnetic zone, as they are scarce in the littoral, and fish in both limnetic and littoral zones. Their diets were evaluated by the analysis of the crop (chaoborid) or stomach contents (fish). Chaoborid larvae consumed the dinoflagellate Peridinium sp. or other algae, rotifers, and planktonic microcrustaceans. The fish species that included microcrustaceans in their diets were juveniles caught in the littoral. Aquatic insects, plant fragments, and detritus were their major dietary items, microcrustaceans representing a minor item. Planktonic copepods contributed more to the diet of chaoborid larvae than planktonic cladocerans. Fish preyed on planktonic microcrustaceans, as well as on benthic and macrophyte-associated species. Microcrustaceans were not heavily preyed on by chaoborid larvae and fish in both reservoirs.

Key words: Chaoborus, cladocerans, copepods, diet, fish.

\section{Introduction}

The predation by invertebrate predators, primarily by Chaoborus larvae (Chaoboridae, Diptera) is high in tropical lentic ecosystems (Saunders and Lewis, 1988; Arcifa, 2000; Bezerra-Neto and Pinto-Coelho, 2002a; Pagano et al., 2003; López and Roa, 2005; Castilho-Noll and Arcifa, 2007a, b). The zooplankton control by invertebrates lasts longer in low latitude lakes due to a longer growing season (Saunders et al., 1999). The chaoborid larvae swallow the whole prey (Pastorok, 1980), and select prey whose size is smaller than the diameter of their mouth. Thus, late larval instars prey on larger organisms, such as microcrustaceans (Swift and Fedorenko, 1975; Moore and Gilbert, 1987; Arcifa, 2000). 
Zooplankton can be also preyed on by fish, although only a few species are truly planktivores in Brazilian water bodies, where other feeding guilds predominate (AraújoLima et al., 1995; Arcifa and Northcote, 1997). Early life stages of fish are the main vertebrate predators, although some small-sized species may include zooplankton in their diets (MaiaBarbosa and Matsumura-Tundisi, 1984; Arcifa et al., 1991; Ambrósio et al., 2001; Roche et al., 2005; Elmoor-Loureiro and Soares, 2010). Predation by juveniles can be large enough to cause the decline of the prey population, such as in the Amazonian Lago Grande, where the decrease of the cladoceran Daphnia gessneri has been attributed to predation by young Colossoma macropomum and turbidity (Carvalho, 1984). However, predation pressure by fish seems to be lower in the limnetic zone than in the littoral, especially in areas with macrophytes, where juveniles and adults of small species are more abundant (Meschiatti et al., 2000; Oliveira et al., 2001; SánchezBotero and Araújo-Lima, 2001; Meschiatti and Arcifa, 2002; Agostinho et al., 2003; Milani et al., 2010).

In shallow and small lentic water bodies, where the littoral and pelagic zones are close, microcrustaceans, including planktonic, benthic and macrophyte-associated species may be preyed on by fish. However, the distribution and abundance of predators and prey determine the predation pressure in the littoral and limnetic zones. Although some studies have shown that littoral macrophytes are avoided by planktonic species (e.g. Dorgelo and Heykoop, 1985; Meerhoff et al., 2006), the diel horizontal migration might be a prey strategy for escaping from predators in shallow temperate lakes (Lauridsen and Buenk, 1996; Burks et al., 2001; 2002). However, macrophytes can be a refuge for zooplankton since the densities of predators, such as fish and invertebrates, are low, as shown in a subtropical Uruguayan lake (Iglesias et al., 2007).

This study aimed at investigating the importance of predation on planktonic and littoral species of microcrustaceans by invertebrate and vertebrate predators in two reservoirs in northwestern São Paulo State.

\section{Material and Methods}

Study area

Samplings were carried out in two small reservoirs, Pindorama and Onda Verde, located in northwestern São Paulo State, Brazil. The reservoirs are situated in rural areas and are used for irrigation. The sampling stations and some characteristics of the reservoirs and surroundings are presented in Table 1. Constructed in the 1970's, the Pindorama Reservoir is fed by three springs, one of them running through a sugar cane plantation, and is devoid of macrophytes. The Onda Verde Reservoir resulted from damming a tributary of São João Stream, in the 1960's. It is surrounded by riparian forest and citrus plantation, and it has stands of macrophytes (Eichhornia azurea, Salvinia auriculata, and some non-identified submerged species).

Table 1. Morphometric features, location and characteristics of the surroundings of Pindorama and Onda Verde reservoirs.

\begin{tabular}{|c|c|c|}
\hline \multirow{2}{*}{ Features } & \multicolumn{2}{|c|}{ Reservoirs } \\
\hline & Pindorama & Onda Verde \\
\hline $\begin{array}{l}\text { Maximum } \\
\text { depth }(m)\end{array}$ & 4.4 & 3.9 \\
\hline $\begin{array}{l}\text { Maximum } \\
\text { length }(\mathrm{m})\end{array}$ & 315.6 & 255.4 \\
\hline $\begin{array}{l}\text { Maximum } \\
\text { width (m) }\end{array}$ & 157.3 & 86.1 \\
\hline $\begin{array}{l}\text { Surface } \\
\text { area }\left(\mathrm{m}^{2}\right)\end{array}$ & 32795 & 11712 \\
\hline Perimeter (m) & 849 & 658 \\
\hline \multirow{2}{*}{ Location } & $21^{\circ} 13^{\prime} 31.4^{\prime \prime} \mathrm{S}$ & $20^{\circ} 33^{\prime} 52^{\prime \prime} \mathrm{S}$ \\
\hline & $48^{\circ} 13^{\prime} 41.5^{\prime \prime} \mathrm{W}$ & $49^{\circ} 16^{\prime} 15.8^{\prime \prime} \mathrm{W}$ \\
\hline Macrophytes & Absent & $\begin{array}{l}\text { Present (floating } \\
\text { and rooted) }\end{array}$ \\
\hline $\begin{array}{l}\text { Riparian } \\
\text { forest }\end{array}$ & $\begin{array}{l}\text { Covering part of } \\
\text { the margins }\end{array}$ & $\begin{array}{c}\text { Present in both } \\
\text { margins }\end{array}$ \\
\hline
\end{tabular}


The climate of the region is Tropical Hot and Rainy (Aw of Köppen), with a dry-cool season (April - September) and a rainy-warm one (October - March).

\section{Sampling and Analysis}

Predators were collected at the beginning of the rainy season (October 2009), which was denominated the dry season, and during the rainy season (March 2010), in both reservoirs.

Chaoborus larvae were collected at dusk in the limnetic zone through vertical hauls with a $65 \mu \mathrm{m}$ meshed net. The volume filtered by the net was calculated by the area of the net mouth and the height of the water column. Organisms were anesthetized with carbonated water and then fixed in $4 \%$ formaldehyde. Samples were not taken in the littoral zone, since previous samplings revealed the extremely low abundance of chaoborid larvae in that site. Zooplankton was studied in four periods in 2009 and the results will be presented elsewhere.

The larvae were measured under a stereomicroscope to identify the instars. Then, with a stylet, the head and part of the digestive tract were extracted and the crop content gently squeezed over a slide, according to Arcifa (2000). The content was examined under a microscope for identification and counting of prey. Instars were selected according to the sizes proposed for Chaoborus brasiliensis Theobald, as follows: instar I = (0.7-1.6 mm); instar II = $(1.7-3.1 \mathrm{~mm})$; instar III $=(3.2-4.7 \mathrm{~mm})$; instar $\mathrm{IV}=(4.8-7.9 \mathrm{~mm})$.

Fish were collected in the limnetic zone using gillnets, $20 \mathrm{~m}$ long and $15 \mathrm{~mm}$ and $35 \mathrm{~mm}$ between knots, set at dusk for four hours. In the littoral zone, the methods were standardized by using a trawl net $(5 \mathrm{~m}$ long, and a $3 \mathrm{~mm}$ meshed net), dip nets and sieves to catch juveniles and smaller species, during two hours in each reservoir, in each sampling period. Fish larvae were sampled by horizontal hauls, with an ichthyoplankton net, in the limnetic zone. Fish were fixed in $10 \%$ formalin and then conserved in $70 \%$ ethanol. Specimens have been deposited in the fish collection DZSJRP under identification numbers from 12989 to 13015 .

After identification, fish were measured with a caliper (standard length) and dissected for the analysis of stomach contents under a stereomicroscope. The volume occupied by each food item was estimated, according to Hyslop (1980), relative to the total content of each stomach $(100 \%)$. Although the diet of the whole fish fauna was evaluated, only the species which fed on microcrustaceans were included here.

\section{Results}

\section{Abundance and diet of Chaoboridae larvae}

In both reservoirs, densities of Chaoborus larvae were larger in the rainy season than in the dry season (Fig. 1). Algae contributed a larger proportion to the diet of chaoborid larvae in the Pindorama Reservoir, whereas microcrustaceans were more important for chaoborid in the Onda Verde Reservoir (Figs. $2,3)$.

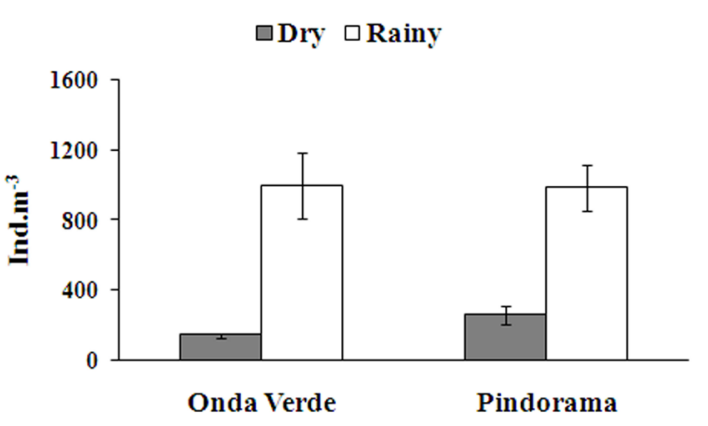

Figure 1. Mean densities $( \pm$ SD) of larvae of Chaoborus sp. in the reservoirs, in the dry and rainy seasons.

The dinoflagellate Peridinium sp. and rotifers were part of the diet of all larval instars in the Pindorama Reservoir, particularly in the rainy season (Fig. 2). Instars III and IV fed on microcrustaceans in a larger proportion in the dry season (Fig. 2A) than in the rainy one (Fig. 2B). The copepods Tropocyclops 

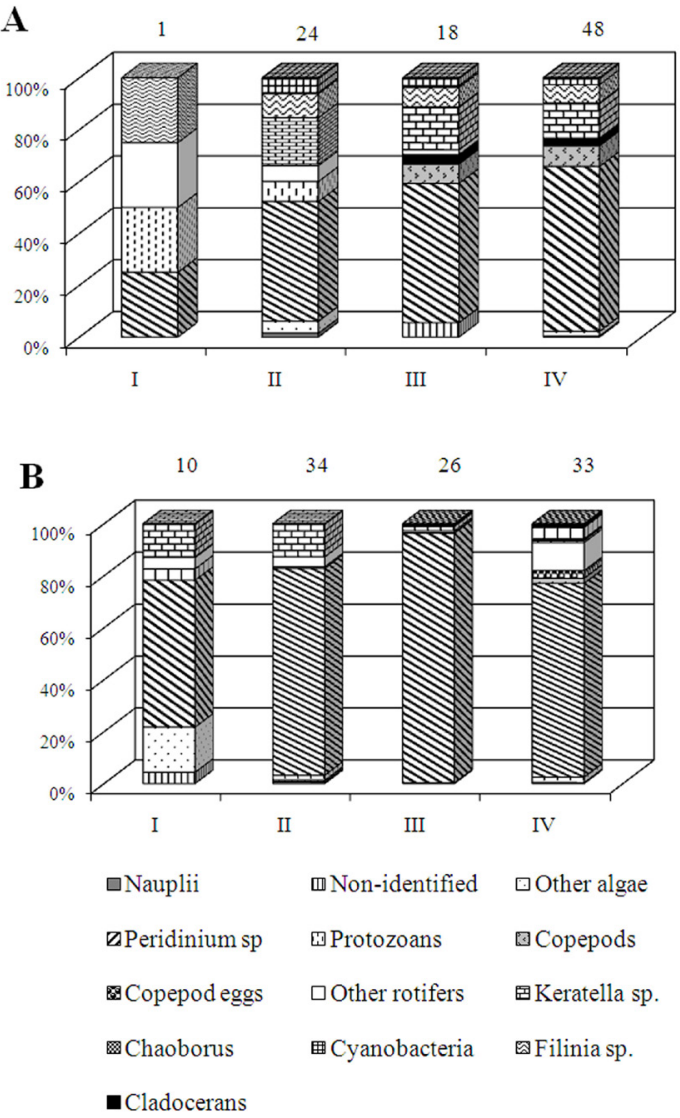

Figure 2. Relative abundance of food items of the four instars of Chaoborus sp., in the Pindorama Reservoir, in the dry (A) and rainy (B) seasons. Numbers on top of the bars are the individuals analyzed.

prasinus meridionalis Kiefer and Thermocyclops decipiens Kiefer contributed more to the diet than cladocerans, which were represented by Daphnia laevis Birge.

Food items differed in the Onda Verde Reservoir, where rotifers represented a major dietary item of all instars, microcrustaceans contributing a low proportion to the diet of the instars III and IV (Fig. 3A). In the rainy season, algae contributed a larger proportion to the diet of all larval instars and microcrustaceans to the diet of the instar IV (Fig. 3B). Both species of planktonic copepods were more consumed than cladocerans, which were mainly represented by Ceriodaphnia cornuta cornuta Sars. Animal items were more abundant in the dry season and algae in the rainy season.

Distribution and diet of fish

Young fish were found only in the
A
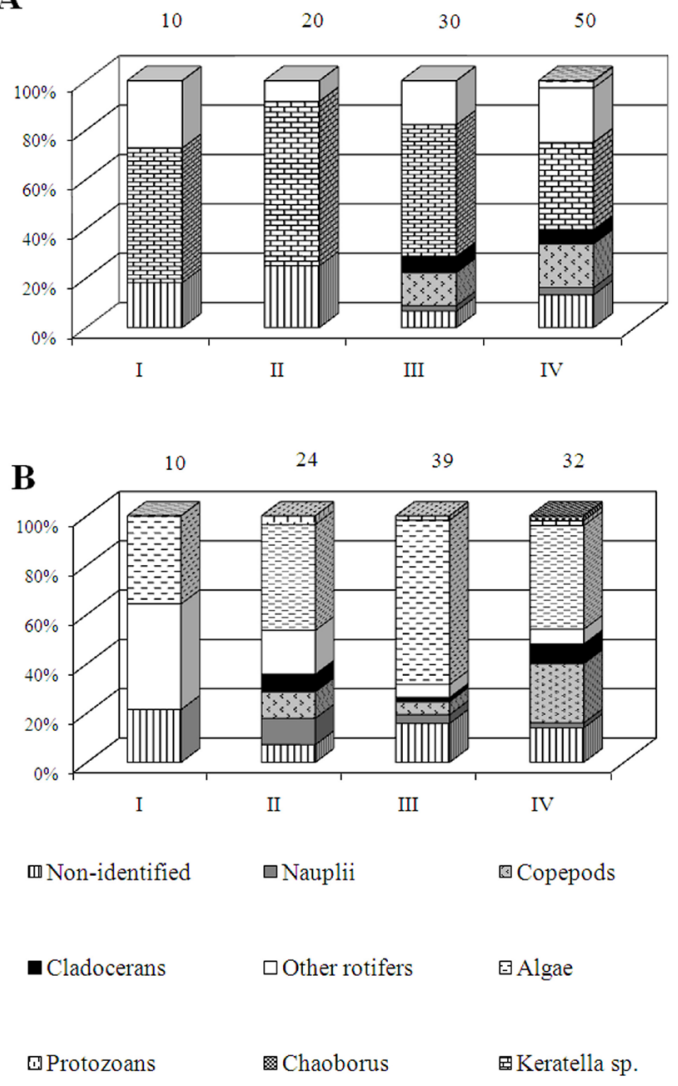

Figure 3. Relative abundance of food items of the four instars of Chaoborus sp., in the Onda Verde Reservoir, in the dry (A) and rainy (B) seasons. Numbers on top of the bars are the individuals analyzed.

littoral zone, especially within the macrophyte stands, when present as in Onda Verde. Fish larvae were not caught in the limnetic zone in either season.

Eleven species of fish were caught in the Pindorama Reservoir, Poecilia reticulata Peters and Oreochromis niloticus (Linnaeus) dominating in the dry season, and Cichla kelberi Kullander \& Ferreira and Cichlasoma paranaense Kullander in the rainy season (Tab. 2). Terrestrial and aquatic insects and detritus (macerated material) were the major dietary items of all fish species. Young $C$. kelberi, C. paranaense, O. niloticus, Astyanax fasciatus (Cuvier), and $P$. reticulata included microcrustaceans in their diets (Tab. 3; Fig. 4). Planktonic copepods, the planktonic cladoceran Daphnia laevis, and the littoral species Macrothrix sp. and Simocephalus serrulatus (Koch) were included in the fish diet. 
Table 2. Fish species and number of individuals caught in Pindorama and Onda Verde reservoirs, in the dry (D) and rainy $(\mathrm{R})$ seasons.

\begin{tabular}{|c|c|c|c|c|}
\hline \multirow[b]{2}{*}{ Family Cichlidae } & \multicolumn{2}{|c|}{ Onda Vede } & \multicolumn{2}{|c|}{ Pindorama } \\
\hline & $\mathrm{D}$ & $\mathrm{R}$ & $\mathrm{D}$ & $\mathrm{R}$ \\
\hline Cichla kelberi Kullander \& Ferreira, 2006 & - & - & - & 558 \\
\hline Cichlasoma paranaense Kullander, 1983 & 52 & 13 & - & 26 \\
\hline Geophagus brasiliensis (Quoy \& Gaimard, 1824) & - & - & 2 & - \\
\hline Oreochromis niloticus (Linnaeus, 1758) & 101 & 5 & 2630 & 3 \\
\hline Tilapia rendalli (Boulenger, 1897) & - & - & 1 & 1 \\
\hline \multicolumn{5}{|l|}{ Family Gymnotidae } \\
\hline Gymnotus pantanal Fernandes et al., 2005 & - & - & - & 1 \\
\hline Gymnotus sylvius Albert \& Fernandes-Matioli, 1999 & 15 & - & - & - \\
\hline \multicolumn{5}{|l|}{ Family Poeciliidae } \\
\hline Poecilia reticulata Peters, 1859 & 469 & 589 & 36 & 3 \\
\hline \multicolumn{5}{|l|}{ Family Loricariidae } \\
\hline Hypostomus ancistroides (Ihering, 1911) & 33 & - & 4 & - \\
\hline \multicolumn{5}{|l|}{ Family Characidae } \\
\hline Astyanax fasciatus (Cuvier, 1819) & - & - & 14 & - \\
\hline Astyanax sp. & 248 & 1 & - & - \\
\hline Oligosarcus pintoi Campos, 1945 & - & - & 1 & - \\
\hline \multicolumn{5}{|l|}{ Family Erithrinidae } \\
\hline Hoplias malabaricus (Bloch, 1794) & 3 & 9 & 1 & 3 \\
\hline
\end{tabular}

Table 3. Volume (\%) and frequency of occurrence (\% in parentheses) of the food items of fish caught in the Pindorama Reservoir. SL = range of standard length of the individuals; $\mathrm{N}=$ number of individuals analyzed; $\mathrm{n}=$ number of individuals with stomach contents.

\begin{tabular}{|c|c|c|c|c|c|c|c|}
\hline \multirow[b]{2}{*}{ Seasons } & \multirow{2}{*}{$\begin{array}{c}\begin{array}{c}\text { Astyanax } \\
\text { fasciatus }\end{array} \\
\text { Dry }\end{array}$} & \multirow{2}{*}{$\begin{array}{l}\text { Cichla } \\
\text { kelberi }\end{array}$} & \multirow{2}{*}{$\begin{array}{c}\begin{array}{c}\text { Cichlasoma } \\
\text { paranaense }\end{array} \\
\text { Rainy }\end{array}$} & \multicolumn{2}{|c|}{ Oreochromis niloticus } & \multicolumn{2}{|c|}{ Poecilia reticulata } \\
\hline & & & & Dry & Rainy & Dry & Rainy \\
\hline $\mathrm{SL}(\mathrm{cm})$ & $1.7-2.7$ & $2.8-6.5$ & $1.2-6.1$ & $2.0-2.7$ & $1.8-7.3$ & $1.8-2.4$ & $1.4-2.3$ \\
\hline $\mathrm{N}$ & 14 & 20 & 20 & 20 & 3 & 20 & 3 \\
\hline $\mathrm{n}$ & 13 & 19 & 19 & 20 & 3 & 20 & 2 \\
\hline Mites & & & & $3.0(5)$ & & & \\
\hline Algae & & & & $2.0(10)$ & $31.5(33)$ & $8.5(15)$ & \\
\hline Cladocerans & $7.3(30)$ & $1.0(5)$ & $2.3(5)$ & & & $0.2(5)$ & \\
\hline Copepods & $21.5(46)$ & & $6.8(26)$ & $2.3(5)$ & $1.5(33)$ & & \\
\hline Detritus & & & $5.4(5)$ & $32.7(35)$ & $34(33)$ & $56.7(60)$ & \\
\hline Plant fragments & & & & $2.0(5)$ & & & \\
\hline Aquatic insects & $29.4(30)$ & $80.5(94)$ & $85(89)$ & $47(45)$ & $33(33)$ & $24.5(30)$ & $82.5(100)$ \\
\hline Terrestrial insects & $29.4(38)$ & $7.4(15)$ & & & & $5.0(5)$ & $5.0(100)$ \\
\hline Non-identified & $7.5(7)$ & & & $10.0(10)$ & & & \\
\hline Ostracods & $4.2(23)$ & $0.5(5)$ & $0.5(10)$ & $0.5(5)$ & & & $12.5(50)$ \\
\hline Copepod eggs & $0.7(7)$ & & & & & & \\
\hline Fish & & $10.5(15)$ & & & & & \\
\hline Shelled amebas & & & & $0.5(5)$ & & $1.0(5)$ & \\
\hline
\end{tabular}

For the two species caught in both seasons, $O$. niloticus and $P$. reticulata, the number of dietary items was larger in the dry season than in the rainy one. Algae and aquatic insects were consumed in larger proportion in the rainy season by $O$. niloticus and $P$. reticulata, 


\section{$\square$ Dry $\square$ Rainy}
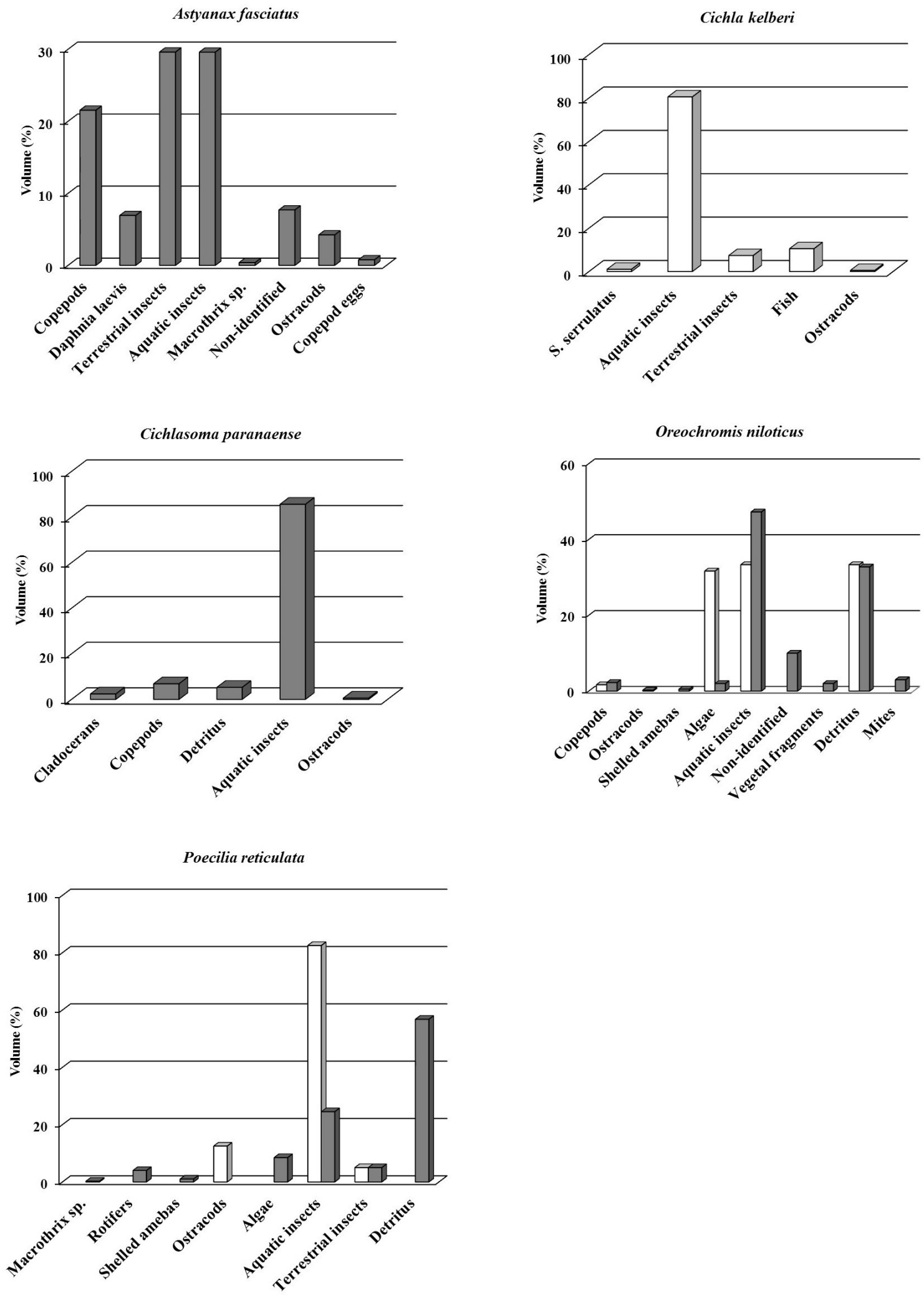

Figure 4. Relative composition of food items in the stomach contents of Astyanax fasciatus, Cichla kelberi, Cichlasoma paranaense, Oreochromis niloticus, and Poecilia reticulata, in the dry and rainy seasons in the Pindorama Reservoir. 
respectively. Microcrustaceans (cladocerans and copepods) contributed $c a .0 .2$ to $9 \%$ to the diet of the fish fauna, except $A$. fasciatus that consumed a larger proportion of copepods (21.5\%) (Tab. 3).

Seven species of fish were recorded in the Onda Verde Reservoir, Poecilia reticulata and Astyanax sp. predominating in the dry season and $P$. reticulata in the rainy season (Tab. 2). Aquatic and terrestrial insects, detritus, and plant fragments were, in general, the main dietary items of fish. Four species fed on microcrustaceans, particularly young $O$. niloticus that consumed $65 \%$ of cladocerans, encompassing the planktonic Moina sp. (50\%) and the macrophyte-associated Chydorus sp. $(15 \%)$, in the rainy season (Tab. 4; Fig. 5). For the other fish species, the contribution of cladocerans and copepods to the diet was lower $(-1.4-5 \%)$, except $P$. reticulata $(19.7 \%$ of cladocerans in the rainy season; Tab. 4). The cladocerans ingested by the four fish species included the planktonic species Ceriodaphnia cornuta cornuta and Moina sp., and the

\section{$\square$ Dry $\square$ Rainy}
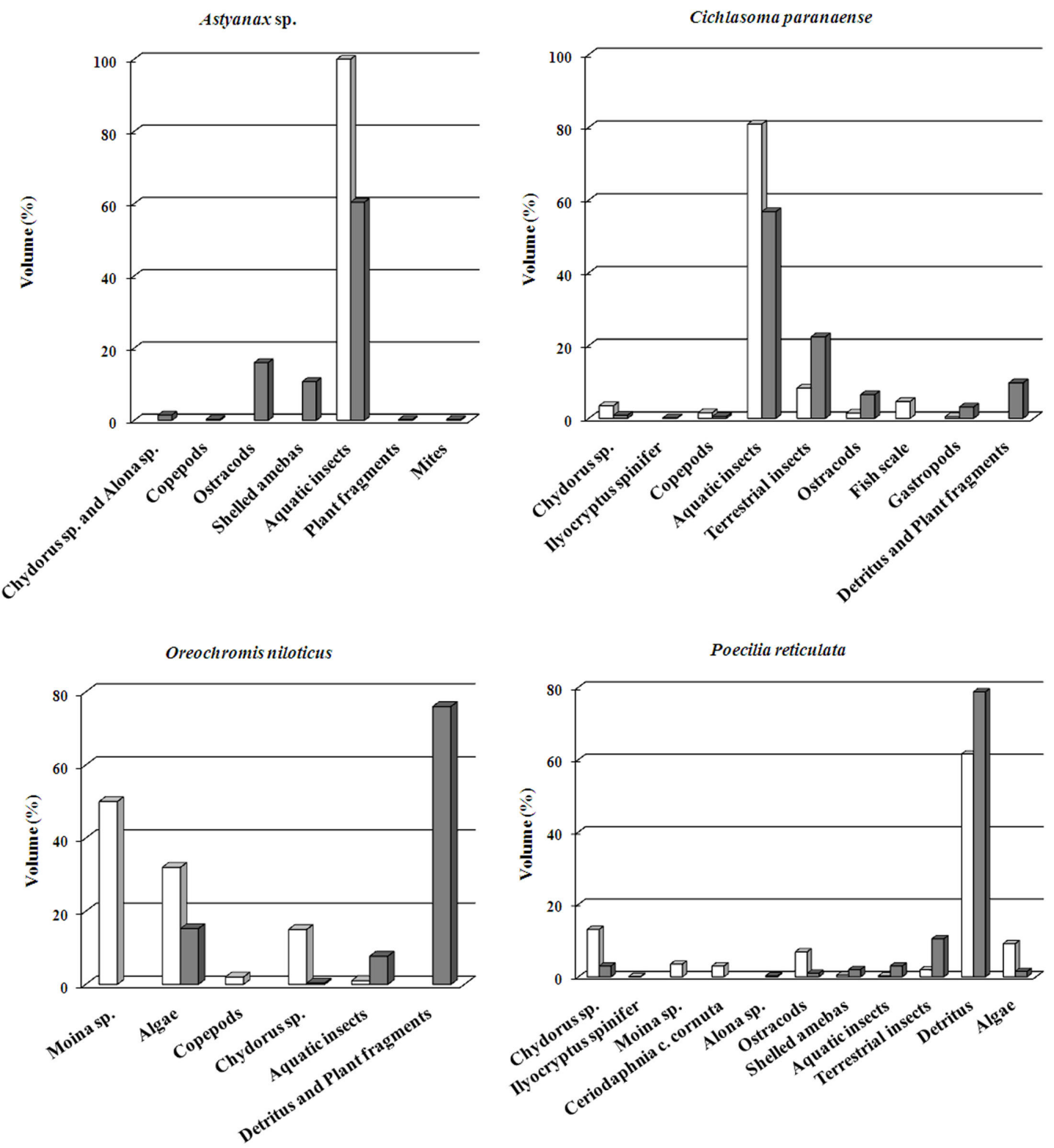

Figure 5. Relative composition of food items in the stomach contents of Astyanax sp., Cichlasoma paranaense, Oreochromis niloticus, and Poecilia reticulata, in the dry and rainy seasons in the Onda Verde Reservoir. 
Table 4. Volume (\%) and frequency of occurrence (\% in parentheses) of the food items of fish caught in the Onda Verde Reservoir. SL = range of standard length of the individuals; $\mathrm{N}$ = number of individuals analyzed; $\mathrm{n}=$ number of individuals with stomach contents.

\begin{tabular}{|c|c|c|c|c|c|c|c|c|}
\hline \multirow[b]{2}{*}{ Seasons } & \multicolumn{2}{|c|}{ Astyanax sp. } & \multicolumn{2}{|c|}{ Cichlasoma paranaense } & \multicolumn{2}{|c|}{ Oreochromis niloticus } & \multicolumn{2}{|c|}{ Poecilia reticulata } \\
\hline & Dry & Rainy & Dry & Rainy & Dry & Rainy & Dry & Rainy \\
\hline $\mathrm{SL}(\mathrm{cm})$ & $2.13-4.49$ & 4.46 & $1.60-4.70$ & $2.56-8.18$ & $1.93-4.25$ & $2.57-3.28$ & $\begin{array}{l}1.80- \\
3.03\end{array}$ & $1.93-2.46$ \\
\hline $\mathrm{N}$ & 20 & 1 & 20 & 13 & 20 & 5 & 20 & 20 \\
\hline $\mathrm{N}$ & 20 & 1 & 20 & 13 & 20 & 5 & 20 & 20 \\
\hline Mites & $0.2(5)$ & & & & & & & \\
\hline Algae & & & & & $15.2(30)$ & $32.0(60)$ & $1.5(5)$ & $9.1(30)$ \\
\hline Cladocerans & $1.5(15)$ & & $0.9(25)$ & $3.4(46)$ & $0.3(10)$ & $65.0(80)$ & $4.5(20)$ & $19.7(45)$ \\
\hline Copepods & $0.3(5)$ & & $0.5(5)$ & $1.5(23)$ & & $2.0(20)$ & & \\
\hline Detritus & & & $9.5(10)$ & & $69.5(75)$ & & $78.7(85)$ & $61.5(75)$ \\
\hline Fish scale & & & & $4.6(23)$ & & & & \\
\hline Plant fragments & $0.2(5)$ & & $0.2(5)$ & & $6.7(25)$ & & & \\
\hline Gastropods & & & $3.1(15)$ & $0.4(23)$ & & & & \\
\hline Aquatic insects & $57(75)$ & $100(100)$ & $56.8(40)$ & $80.4(100)$ & $8.2(15)$ & $1.0(20)$ & $3.0(5)$ & $0.3(5)$ \\
\hline Terrestrial insects & $14.2(35)$ & & $22.4(25)$ & $8.3(23)$ & & & $10.5(15)$ & $1.9(25)$ \\
\hline Ostracods & $16.0(50)$ & & $6.5(10)$ & $1.4(30)$ & & & $1.0(15)$ & $6.9(35)$ \\
\hline Shelled amebas & $10.6(40)$ & & & & & & $2.0(20)$ & $0.6(5)$ \\
\hline
\end{tabular}

macrophyte-associated Alona sp., Chydorus sp., and Ilyocryptus spinifer Herrick (Fig. 5).

\section{Discussion}

\section{Diet of Chaoboridae larvae}

The highest densities of Chaoborus sp. in the rainy-warm season have been also observed in the tropical Lake Monte Alegre, where the decline of some cladoceran species was related with increased densities of chaoborid larvae (Arcifa et al., 1992).

The larger contribution of algae to the chaoborid diet in the Pindorama Reservoir, in comparison to the Onda Verde Reservoir, might be related to the fact that its algae biomass is high (Câmara, 2011). Shift in food items from one season to another, observed here, could be a way to maximize the exploitation of fluctuating resources. The use of alternative food items by chaoborid larvae, in the seasons, agrees with findings in the Brazilian Lake Monte Alegre (Arcifa, 2000).

The major contribution of Peridinium sp. to the diet of chaoborid larvae in Pindorama points to the omnivorous habit of chaoborid larvae, which is in accordance with data from other lakes (Hare and Carter, 1987; Moore et al. 1994; Arcifa, 2000). Owing to the small size of Peridinium sp., however, its contribution in biomass is low (Castilho-Noll and Arcifa, 2007a). The vulnerability of rotifers to predation by Chaoborus depends on several aspects such as the lorica texture, body length, and type of swimming movement (Moore and Gilbert, 1987). A few species of rotifers were preyed on by the larvae among the 14 species present in the plankton (J. Abra, personal communication), with preference for Keratella sp. as observed by other authors (Bezerra-Neto and Pinto-Coelho, 2002b; Castilho-Noll and Arcifa, 2007a, b). Apparently, the presence of spines does not prevent the predation of Keratella by chaoborid larvae, which is favored by its high densities in Pindorama (J. Abra, personal communication) and its low escape ability. The low consumption of nauplii by Chaoborus larvae observed in this study, as well as in others (López and Roa, 2005; CastilhoNoll and Arcifa, 2007a, b) may result from an underestimated number owing to their quick digestion (Fedorenko, 1975; Moore, 1988).

The preference for copepods in comparison to cladocerans, in the Pindorama Reservoir, was probably related to their smaller 
size than the limnetic cladoceran Daphnia laevis. A dominant cladoceran during most of the study, it has a large body size (maximum $1.64 \mathrm{~mm}$ ), individuals larger than $0.70 \mathrm{~mm}$ predominating in the population. Therefore, only juveniles are preyed on by the chaoborid larvae, agreeing with data from the Lake Monte Alegre (Arcifa, 2000; Castilho-Noll and Arcifa, 2007b). These authors report that only young Daphnia gessneri and D. ambigua (length 0.48 - $0.80 \mathrm{~mm}$ ) were preyed on by the instars III and IV. The copepod prey, Thermocyclops decipiens and Tropocyclops prasinus meridionalis, are smaller than cladocerans $(0.40-0.84$ $\mathrm{mm}$ ), and as they have spineless bodies they can be more easily ingested. They contribute a larger biomass to the diet of Chaoborus larvae (Castilho-Noll and Arcifa, 2007a) than smaller organisms, such as Peridinium sp. and rotifers.

Similarly to findings in Pindorama, the contribution of copepods prevailed in Onda Verde. The predominance of Ceriodaphnia cornuta cornuta, among the cladocerans, in the chaoborid diet could be favored by its suitable size $(0.18-0.46 \mathrm{~mm})$ and the dominance in the plankton. Contrasting results have been found regarding predation on $C$. cornuta by chaoborid larvae. López and Roa (2005) report a positive selection of $C$. cornuta by chaoborid fourth instar in a Venezuelan lake, whereas Arcifa (2000) found, in a Brazilian lake, a low proportion of $C$. cornuta in the diet of Chaoborus, which selected Bosmina tubicen Brehm, even during a high peak of $C$. cornuta in the lake. The presence of lateral spines in $C$. cornuta may lower the ingestion by Chaoborus, despite the adequate size placing Ceriodaphnia as a potential prey (Mumm, 1997; Pagano et al., 2003).

Although the contribution of planktonic cladocerans to the diet of chaoborid larvae was relatively low in Onda Verde (maximum $6.5 \%$ ) we may suppose that the effect on the population dynamics can be significant. Castilho-Noll and Arcifa (2007a) reported that the contribution of Daphnia gessneri to the diet of instar IV, that has not exceeded $10 \%$, was sufficient to cause a significant higher mortality rate and lower population growth rate in the treatment with chaoborid larvae than in the Chaoborus - free treatment in mesocosm experiments. On the other hand, despite a larger proportion of copepods than cladocerans in the chaoborid diet, their population dynamics has not been influenced by predation. According to the authors, one of the reasons could be a larger production of eggs that results in higher recruitment, reducing the effects of predation, the same way we suppose happened here with Thermocyclops decipiens and Tropocyclops prasinus meridionalis, as they produced a high number of eggs.

A wider amplitude of food items with the inclusion of microcrustaceans, mostly in the diet of instars III and IV of Chaoborus in the reservoirs, can favor their biomass growth. The diversification of food items in the last instars can contribute to increasing the allocation of energy to body mass, as the biomass production is largest in the late instar (Bezerra-Neto and Pinto-Coelho, 2002c). As the predator mouth diameter and the maximum width, height, or diameter of the prey are related (Arcifa, 2000), and larger larvae can consume larger prey, last instars were benefited by the extra energy provided by larger items, in both reservoirs.

Summarizing the overall diet, in Pindorama the food items of chaoborid instars can be ranked Peridinium > rotifers $>$ protozoans and Peridinium > rotifers > copepods > cladocerans, respectively for the instars I-II and III-IV, in both seasons (except for the instar I, in the dry season, where rotifers $>$ Peridinium and protozoans). In Onda Verde, the diet was more diversified and varied in the seasons. Rotifers predominated in the diet of early instars in the dry season, whereas a larger number of items occurred in the rainy season, in the following order of importance - algae > rotifers $>$ copepods $>$ cladocerans. There was a shift in the diet of the instars III and IV, the items following this order - rotifers $>$ copepods $>$ cladocerans in the dry season, and algae > copepods > cladocerans and rotifers, in the rainy season. 


\section{Diet of fish}

Of the thirteen fish species recorded, three are exotic (Oreochromis niloticus, Tilapia rendalli and Poecilia reticulata) and one was introduced from the Amazon Basin (Cichla kelberi). The other species belong to the Upper Paraná River basin (Casatti et al., 2009), except Gymnotus pantanal described from the Pantanal Matogrossense, the Paraguay River and Guaporé, Bolivia (Fernandes et al., 2005).

Young fish and adults of smaller species can use the littoral zone, particularly the macrophyte stands, as refuge against piscivorous fish (Roche and Rocha, 2005), and the early stages also use these habitats for development (Esguícero and Arcifa, 2010). Therefore, predation by fish on microcrustaceans is potentially higher in the littoral than in the limnetic zone.

The large contribution of aquatic insects to the diet of fish in this study has also been found in other Brazilian water bodies (e.g. Meschiatti et al., 2000; Oliveira et al., 2001; Meschiatti and Arcifa, 2002). Microcrustaceans were a minor dietary item here as in most Brazilian water bodies, where planktivorous fish are usually absent in the limnetic zone (Araújo-Lima et al., 1995; Arcifa and Northcote, 1997), microcrustaceans being preyed on by young fish or smaller species, especially in littoral areas of the water bodies.

Astyanax fasciatus was an exception regarding microcrustacean predation, in Pindorama, as the contribution of microcrustaceans, particularly copepods, was large. In general, $A$. fasciatus feeds mostly on insects and algae, but microcrustaceans can be a major item in some water bodies. In the Americana Reservoir, planktonic cladocerans, such as Bosmina, Diaphanosoma, Daphnia, and Moina were commonly ingested by juveniles and adults of $A$. fasciatus (Arcifa et al., 1991). Copepods and cladocerans were major dietary items of both young and adult of this species in the Broa Reservoir (Maia-Barbosa and Matsumura-Tundisi, 1984). Although in Pindorama Daphnia laevis was consumed by $A$. fasciatus, the density of the cladoceran was low in the littoral zone, what may have contributed to the larger proportion of copepods in the diet of $A$. fasciatus. A lower contribution of microcrustaceans than aquatic insects to the diet of Astyanax sp. in Onda Verde was probably related to the higher abundance of insects within the macrophyte stands.

The ingestion of littoral cladocerans such as Chydorus, Alona, and Ilyocryptus by young Cichlasoma paranaense, Oreochromis niloticus, and Poecilia reticulata is probably related to the way they forage in the littoral zone. These cladocerans have specializations to live at the bottom or in the middle of the vegetation, such as appendages and spines that allow scraping the food and moving around in these environments (Souza and ElmoorLoureiro, 2008).

There is ontogenetic variation in the diet of Cichla kelberi in Pindorama Reservoir, the juveniles having a more diversified diet than the piscivorous adult fish, which included mainly aquatic insects and a low number of the large-sized littoral cladoceran Simocephalus serrulatus. The same variation has been reported for $C$. ocellaris in the Lake Monte Alegre, where juveniles fed on aquatic insects and secondarily on zooplankton and fish (Arcifa and Meschiatti, 1993).

The low number of planktivorous fish species in Brazilian water bodies leads to the prevalence of Chaoborus predation on zooplankton in the limnetic zone. In some lakes the increased predation by Chaoborus is caused by the introduction of a piscivorous fish, evidencing a top-down effect. In lakes of the Rio Doce Valley, the introduction of the cichlid Cichla cf. ocellaris and the characid Pygocentrus nattereri caused the extinction of native fish species, favoring the increase of chaoborid larvae, with the consequent disappearance of several cladoceran species (Pinto-Coelho et al., 2008).

\section{Conclusion}

In both reservoirs, planktonic and 
littoral microcrustaceans are preyed on by fish nearshore, and planktonic species by Chaoborus larvae in the limnetic zone. Predation by chaoborid larvae on microcrustaceans is lower than on other items, such as Peridinium sp. and rotifers, while aquatic insects, plant fragments and detritus are more consumed by fish. Fish species selected larger prey, such as aquatic insects, whereas the smaller microcrustaceans represented a minor dietary item. Chaoborus preferred smaller prey, such as Peridinium sp., rotifers, protozoans, copepods, and juveniles of large cladocerans. Although predation on microcrustaceans is not heavy, the extension of its influence on the population dynamics is still unknown in the reservoirs.

\section{Acknowledgments}

We thank FAPESP for a grant to CFC (2008/08560-7), the financial support (BIOTA/FAPESP Program, 04/04820-3) and a Post-Doctoral fellowship to MSMCN (07/05134-4). We also thank CAPES for a grant to CFC, for developing her Master Thesis, and the Laboratory of Ichthyology, Department of Zoology and Botany, UNESP, São José do Rio Preto, for helping to identify the fish species, as well as LHS da Silva and an anonymous reviewer for their suggestions.

\section{References}

Agostinho, A.A.; Gomes, L.C. and Julio, H.F. Jr. 2003. Relaçôes entre macrófitas aquáticas e fauna de peixes. p. 261-279. In: S.M. Thomaz, L.M. Bini (eds), Ecologia e Manejo de Macrófitas Aquáticas. Maringá, EDUEM.

Ambrósio, A.M.; Agostinho, A.A.; Gomes, L.C. and Okada, E.K. 2001. The fishery and fishery yield of Hypophtalmus edentatus (Spix, 1829), (Siluriformes, Hypophthalmidae), in the Itaipu reservoir, Paraná state, Brazil. Acta Limnologica Brasiliensia, 13(1): 93-105.
Araújo-Lima, C.A.R.M.; Agostinho, A.A. and Fabré, N.N. 1995. Trophic aspects of fish communities in Brazilian Rivers and Reservoirs. p. 105-136. In: T. Tundisi, C.E.M. Bicudo, T. Matsumura-Tundisi (eds), Limnology in Brazil. Rio de Janeiro, Brazilian Academy of Sciences, Brazilian Limnological Society.

Arcifa, M.S. 2000. Feeding habits of Chaoboridae larvae in a Tropical Brazilian Reservoir. Revista Brasileira de Biologia, 60(4): 591-597.

Arcifa, M.S.; Gomes, E.A.T. and Meschiatti, A.J. 1992. Composition and fluctuations of the zooplankton of a tropical Brazilian reservoir. Archiv für Hydrobiologie, 123: 479-495.

Arcifa, M.S.; Northcote, T.G. and Froehlich, O. 1991. Interactive ecology of two cohabiting characin fishes (Astyanax fasciatus and Astyanax bimaculatus) in an eutrophic Brazilian reservoir. Journal of Tropical Ecology, 7: 257-268.

Arcifa, M.S. and Meschiatti, A.J. 1993. Distribution and feeding ecology of fishes in a Brazilian reservoir: Lake Monte Alegre. Interciencia, 18(6): 83-87.

Arcifa, M.S. and Northcote, T.G. 1997. Need for holistic approaches in food web experiments and biomanipulation in tropical lakes: a Brazilian reservoir experience. Verhandlungen der Internationale Vereinigung für Limnologie, 26: 661-665.

Bezerra-Neto, J.F. and Pinto-Coelho, R.M. 2002a. A influência da larva de Chaoborus brasiliensis (Theobald, 1901) (Diptera, Chaoboridae) na distribuição vertical da comunidade zooplanctônica da lagoa do Nado, Belo Horizonte, Estado de Minas Gerais. Acta Scientiarum - Biological Sciences, 24(2): 337-344.

Bezerra-Neto, J.F. and Pinto-Coelho, R.M. 2002b. Migração vertical das larvas de Chaoborus brasiliensis (Diptera: Chaoboridae) em um reservatório tropical: lagoa da Nado, Belo Horizonte, Estado de Minas Gerais. Acta Scientiarum - Biological 
Sciences, 24(2): 329-336.

Bezerra-Neto, J.F. and Pinto-Coelho, R.M. 2002c. Population dynamics and secondary production of Chaoborus brasiliensis (Diptera, Chaoboridae) in a small tropical reservoir: Lagoa do Nado, Belo Horizonte, Minas Gerais - Brazil. Acta Limnologica Brasiliensia, 14(3): 61-72.

Burks, R.L.; Jeppesen, E. and Lodge, D.M. 2001. Littoral zone structures as refugia against fish predators. Limnology and Oceanography, 46: 230-237.

Burks, R.L.; Lodge, D.M.; Jeppesen, E. and Lauridsen, T.L. 2002. Diel horizontal migration of zooplankton: costs and benefits of inhabiting the littoral. Freshwater Biology, 47: 343-365.

Câmara, C.F. 2011. Caracterização da comunidade de microcrustáceos zooplanctônicos e avaliação de potenciais predadores vertebrados e invertebrados em dois reservatórios na região noroeste do Estado de São Paulo. Master Thesis, Universidade Estadual Paulista, São José do Rio Preto. 140 p.

Carvalho, M.L. 1984. Influence of predation by fish and water turbidity on a Daphnia gessneri population in an Amazonian floodplain lake, Brazil. Hydrobiologia, 113: 243-247.

Casatti, L.; Ferreira, C.P. and Langeani, F. 2009. A fish-based biotic integrity index for assessment of lowland streams in southeastern Brazil. Hydrobiologia, 623: 173-189.

Castilho-Noll, M.S.M. and Arcifa, M.S. 2007a. Mesocosm experiment on the impact of invertebrate predation on zooplankton of a tropical lake. Aquatic Ecology, 41: 587-598. Castilho-Noll, M.S.M. and Arcifa, M.S. 2007b. Chaoborus diet in a tropical lake and predation of microcrustaceans in laboratory experiments. Acta Limnologica Brasiliensia, 19(2): 163-174.

Dorgelo, J. and Heykoop, M. 1985. Avoidance of macrophytes by Daphnia longispina. Verhandlungen der Internationale
Vereinigung für Limnologie, 22: 3369-3372.

Elmoor-Loureiro, L.M.A. and Soares, C.E.A. 2010. Cladocerans from gut content of fishes from Guaporé River Basin, MT, Brasil. Acta Limnologica Brasiliensia, 22(1): 46-49.

Esguícero, A.L.H. and Arcifa, M.S. 2010. Which is the best environment for the development of the early life stages of fish during the dry season? Acta Limnologica Brasiliensia, 22(3): 1-9.

Fedorenko, A.Y. 1975. Feeding characteristics and predation impact of Chaoborus (Diptera, Chaoboridae) larvae in a small lake. Limnology and Oceanography, 20: 250258.

Fernandes, F.M.C.; Albert, J.S.; Daniel-Silva, M.F.Z.; Lopes, C.E.; Cramptom, W.G. R. and Almeida-Toledo, L.F. 2005. A new Gymnotus (Teleostei: Gymnotiformes: Gymnotidae) from the Pantanal Matogrossense of Brazil and adjacent drainages: continued documentation of a cryptic fauna. Zootaxa, 933: 1-14.

Hare, L. and Carter, J.H. 1987. Zooplankton populations and the diets of three Chaoborus species (Diptera, Chaoboridae) in a tropical lake. Freshwater Biology, 17: 275-290.

Hyslop, E.J. 1980. Stomach contents analysis - a review of methods and their application. Journal of Fish Biology, 17: 411-429.

Iglesias, C.; Goyenola, G.; Mazzeo, N.; Meerhoff, M.; Rodó, E. and Jeppesen, E. 2007. Horizontal dynamics of zooplankton in subtropical Lake Blanca (Uruguay) hosting multiple zooplankton predators and aquatic plant refuges. Hybrobiologia, 584: 179-189.

Lauridsen, T.L. and Buenk, I. 1996. Diel changes in the horizontal distribution of zooplankton in the littoral zone of two shallow eutrophic lakes. Archiv für Hydrobiologie, 137: 167-176.

López, C. and Roa, E.Z. 2005. Day-night vertical distribution and feeding patterns of fourth instar of Chaoborus larvae in a neotropical reservoir (Socuy Reservoir, 
Venezuela). International Review of Hydrobiology, 90(2): 171-184.

Maia-Barbosa, P.M. and Matusumura-Tundisi, T. 1984. Consumption of zooplanktonic organisms by Astyanax fasciatus Cuvier, 1819 (Osteichthyes Characidae) in Lobo (Broa) Reservoir, São Carlos, SP, Brazil. Hydrobiologia, 113: 171-181.

Meerhoff, M.; Fosalba, C.; Bruzzone, C.; Mazzeo, N.; Noordoven, W. and Jeppesen, E. 2006. An experimental study of habitat choice by Daphnia: plants signal danger more than refuge in subtropical lakes. Freshwater Biology, 51: 1320-1330.

Meschiatti, A.J.; Arcifa, M.S. and FenerichVerani, N. 2000. Fish communities associated with macrophytes in Brazilian floodplain lakes. Environmental Biology of Fishes, 58: 133-143.

Meschiatti, A.J. and Arcifa, M.S. 2002. Early life stages of fish and the relationships with zooplankton in a tropical Brazilian Reservoir: Lake Monte Alegre. Brazilian Journal of Biology, 62(1): 41-50.

Milani, V.; Machado, F.A. and Silva, V.C.F. 2010. Assembléias de peixes associados às macrófitas aquáticas em ambientes alagáveis do Pantanal de Poconé, MT, Brasil. Biota Neotropica, 10(2): 261-270.

Moore, M.V. 1988. Differential use of food resources by the instars of Chaoborus punctipennis. Freshwater Biology, 19(2): 249-268.

Moore, M.V. and Gilbert, J.J. 1987. Agespecific Chaoborus predation on rotifer prey. Freshwater Biology, 17(2): 223-236.

Moore, M.; Yan, N.D. and Pawson, T. 1994. Omnivory of the larval phantom midge (Chaoborus spp.) and its potential significance for freshwater planktonic food webs. Canadian Journal of Zoology, 72: 2055-2065.

Mumm, H. 1997. Effects of competitors and Chaoborus predation on the cladocerans of a eutrophic lake: an enclosure study. Hydrobiologia, 360: 253-264.

Oliveira, E.F.; Luiz, E.A.; Agostinho, A.A. and
Benedito-Cecilio, E. 2001. Fish assemblages in littoral areas of the upper Paraná river floodplain, Brazil. Acta Scientiarum Biological Sciences, 23(2): 369-376.

Pagano, M.; Koffi, M.A.; Cecchi, P.; Corbin, D.; Champalbert, G. and Saint-Jean, L. 2003. An experimental study of the effects of nutrient supply and Chaoborus predation on zooplankton communities of a shallow tropical reservoir (Lake Brobo, Côte d'Ivoire). Freshwater Biology, 48: 13791395.

Pastorok, R.A. 1980. Selection of prey by Chaoborus larvae: a review and new evidence for behavioral flexibility. p. 538-554. In: W.C. Kerfoot (ed), Evolution and Ecology of Zooplankton Communities. London, University Press of New England.

Pinto-Coelho, R.M.; Bezerra-Neto, J.F.; Miranda, F.; Mota, T.G.; Resck, R.; Santos, A.M.; Maia-Barbosa, P.M.; Mello, N.A.S.T.; Marques, M.; Campos, M.O. and Barbosa, F.A.R. 2008. The inverted trophic cascade in tropical plankton communities: Impacts of exotic fish in the Middle Rio Doce lake district, Minas Gerais, Brazil. Brazilian Journal of Biology, 68(4, Suppl.): 10251037.

Roche, K.F. and Rocha, O. 2005. Aspectos de predação por peixes em lagos e represas, com enfoque na planctivoria. p. 1-24. In: K. Roche and O. Rocha (orgs), Ecologia Trófica de Peixes com Ênfase na Planctivoria em Ambientes Lênticos de Água Doce no Brasil. São Carlos, Editora Rima.

Roche, K.F.; Rietzler, A.C. and Rocha, O. 2005. Dieta de Astyanax bimaculatus, Cheirodon stenodon, Serrasalmus spilopleura e Plagioscion squamosissimus em duas represas com ênfase nos indivíduos juvenis. p. 8192. In: K. Roche and O. Rocha (orgs), Ecologia Trófica de Peixes com Ênfase na Planctivoria em Ambientes Lênticos de Água Doce no Brasil. São Carlos, Editora Rima.

Sánchez-Botero, J.I. and Araújo-Lima, C.A.R.M. 2001. As macrófitas aquáticas 
como berçário para a ictiofauna da várzea do Rio Amazonas. Acta Amazonica, 31(3): 437-447.

Saunders, J.F. III and Lewis, W.M., Jr. 1988. Dynamics and control mechanisms in a tropical zooplankton community (Lake Valencia, Venezuela). EcologicalMonographs, 58: 337-353.

Saunders, P.A.; Porter, K.G. and Taylor, B.E. 1999. Population dynamics of Daphnia spp. and implications for trophic interactions in a small, monomictic lake. Journal of Plankton Research, 21: 1823-1845.

Souza, F.D.R. and Elmoor-Loureiro, L.M.A. 2008. Cladóceros fitófilos (Crustacea, Branchiopoda) do Parque Nacional das Emas, estado de Goiás. Biota Neotropica, 8(1): 159-166.

Swift, M.C. and Fedorenko, A.Y. 1975. Some aspects of prey capture by Chaoborus larvae. Limnology and Oceanography, 20(3): 418425. 